\title{
RECOUNTING AS REALIZATION OF BROWN AND LEVINSON'S POSITIVE POLITENESS STRATEGIES IN INSTRUCTIONAL INTERACTIONS
}

\author{
Agung Pramujiono*, Suhari, Tri Indrayanti, Dyah Rochmawati \\ Pendidikan Bahasa Indonesia, Fakultas Keguraun dan Ilmu Pendidikan, Universitas PGRI Adi Buana Surabaya, \\ Jln. Dukuh Menanggal XII/3 Surabaya, Indonesia \\ *Corresponding author: agungpramujiono@unipasby.ac.id
}

\section{INFORMASI ARTIKEL}

Sejarah Artikel

Diterima: 8/10/2019

Direvisi: $14 / 11 / 2019$

Diterima: $19 / 11 / 2019$

Tersedia Daring: 28/12/2019

Kata Kunci

Bercerita

Strategi Kesantunan Positif

Interaksi Instruksional

\section{ABSTRAK}

Dalam interaksi instruksional, seorang dosen dituntut mampu membangun harmoni di kelas sehingga terbangun suasana kelas yang kondusif sehingga tujuan pembelajaran dapat tercapai. Penelitian ini bertujuan mendeskripsikan bercerita sebagai realisasi strategi kesantunan positif Brown dan Levinson dalam interaksi instruksional di kelas. Subjek penelitian ini adalah enam orang dosen Universitas Kristen Satya Wacana Salatiga. Data penelitian berupa ujaran dosen dalam perkuliahan. Data dikumpulkan dengan menggunakan metode simak dengan teknik rekam dan wawancara mendalam. Analisis data dilakukan dengan menggunakan teknik deskriptif mengikuti model alir Miles dan Huberman. Berdasarkan hasil analisis data ditemukan cerita yang digunakan meliputi cerita tentang diri dosen, cerita tentang mahasiswa, cerita tentang pengalaman dosen, dan cerita tentang tokoh/sikap tokoh. Selain berfungsi membangun kedekatan hubungan dengan interaktan, strategi bercerita juga berfungsi untuk menanamkan nilai karakter dan untuk memotivasi mahasiswa.

\section{ABSTRACT}

Keywords

Storytelling

Positive Politeness Strategies

Instructional Interactions
In instructional interactions, a lecturer should be able to build harmony in a conducive classroom atmosphere in order that a learning objective can be attained. This study aims to describe recounting as the realization of Brown and Levinson's positive politeness strategies in instructional interactions in the classroom. The subjects of this study were six lecturers from the Satya Wacana Christian University Salatiga. The research data were in the form of lecturer utterances when lecturing. The data were collected using the participant observation. The data analysis was performed using descriptive techniques following the Miles and Huberman flow model. Based on the results of data analysis, it revealed that the recounts employed included ones about lecturers, students, lecturers' experiences, and public figures/attitudes of public figures. These findings can be used to strengthen and revise the positive politeness sub-strategies of Brown and Levinson (1987). In addition to functioning to forge a close relationship with interactants, the recounting strategy also serves to instill character values and to motivate students to be more disciplined, and to optimize their own potential of becoming creative students. The use of recount as a positive politeness sub-strategy has contributed to the efforts of creating humanistic-based learning.

Copyright@2019, Agung Pramujiono, Suhari, Tri Indrayanti, Dyah Rochmawati This is an open access article under the $\mathrm{CC}-\mathrm{BY}-3.0$ license
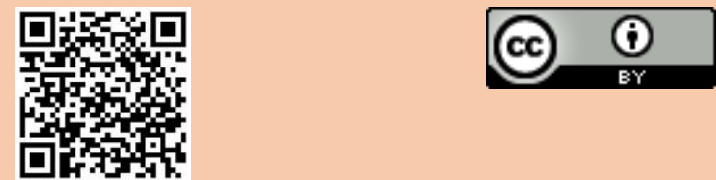


\section{INTRODUCTION}

In instructional interaction, lecturers play diverse roles and functions. In addition to having required abilities to plan and facilitate learning well, they must also be able to create a conducive classroom atmosphere so that enables learning practices to take place well (Pramujiono \& Nurjati, 2017). With a conducive classroom atmosphere it is hoped that learning objectives can be well achieved.

In learning, lecturers and students as interactants in instructional interactions need to take into consideration each other's faces, both their faces and the faces of their speech partners. This needs to be done to avoid the face-threatening acts in interactions (Brown, Levinson, \& Levinson, 1987; Scollon, Scollon, \& Jones, 2011). A politeness strategy needs to be applied to build harmony in the classroom so that the interactions can avoid potential conflicts (Leech, 2016).

Numerous studies on language politeness strategies in a wide variety of contexts seek to describe the use of five language politeness strategies developed by (Brown et al., 1987). This phenomenon has attracted many researchers. Pramujiono (2008) examined the use of politeness strategies in doctor-patient communication, and examined the use of politeness strategies in dialogue discourses on TV (Pramujiono, 2012). Senowarsito (2013) and Mahmud (2018) studied the use of politeness strategies in learning English as a Second Language. Getkham (2013) examined the politeness strategies in research article; Pramujiono and Nurjati (2017) examined the use of politeness strategies in instructional interactions in the elementary schools. Generally these studies have dealt with ways of how the use of Brown and Levinson's politeness strategies (1987) was in a particular context. How the theory is workable in an academic setting, that is, the use of politeness in classroom interactions has been rarely investigated, and hence this study is to fill in this gap. This research attempted at exploring and discovering the positive politeness sub-strategies that are used to establish the closeness of lecturers and students in learning. The politeness strategies used by the lecturers play an important role in establishing a successful lecturer-student communication which will ultimately lead to the success of the students' learning. The research findings are expected to provide reinforcement and revise Brown and Levinson's positive politeness theory (1987).

From the lens of Brown et al. (1987), politeness in language is a way to preserve and save face. This is based on the assumption that most speech acts always threaten the faces of speakers and speech partners. The politeness strategy is an effort to mitigate the level of threat to the face (Pramujiono, 2008). In the perspective of politeness of Brown et al. (1987), the level and type of politeness that applies to certain speech acts is influenced by the specificity of politeness that is calculated by a speaker based on three variables, namely (1) social distance (D). This variable will affect the level of familiarity and solidarity between the speaker and the speech partner; (2) the difference in power $(\mathrm{P})$ perceived by the speaker and the speech partner; and (3) the ranking of speech act threats in a particular cultural context (R), i.e. how much "threat" or how much "danger" is perceived to exist in a particular cultural context.

Furthermore, Brown et al. (1987) explained that in the face-threatening act a model person can employ one of the five strategies offered, namely (1) direct speech acts/saying things in a direct, clear, unambiguous and concise way (bald on record), (2) speech acts using positive politeness strategies, (3) speech acts using negative politeness strategies, (4) speech acts in a disguised/indirect manner (off record), and (5) speaking in the heart or not doing speech acts.

Brown and Levinson's positive politeness strategy (Pramujiono, 2008) has 15 substrategies, namely (1) paying attention to the listener's wants, desires, and needs, (2) exaggerating the attention, approval, and sympathy of the listener, (3) intensifying the listener's attention by dramatization of events or facts, (4) using group identity (forms of greeting, 
dialect, jargon or slang), (5) seeking agreement on a general topic or repeating parts/ all of the utterances, (6) avoiding disagreement by pretending to agree, pseudo-agreement, deceptive for good (white lies), hedging opinion. (7) showing things that are considered to have similarities through small talk and presuppositions, (8) using jokes, (9) stating that the listener's desires are understood, (10) giving an offer or promise, (11) showing optimism, (12) involving speakers or listeners in activities, (13) giving questions or asking reasons, (14) expressing reciprocal relationships, and (15) giving special attention (goods, sympathies, attention, cooperation) to the listener.

In this study, the researchers focused on the use of recounting strategies as a positive politeness substrategy. In the opinion of the researchers, the recounting strategy can be included in the positive politeness substrategy because it also aims to reduce the distance and build a close relationship between the speaker and the speech partner as the essence of positive politeness. In instructional interactions, this phenomenon is interesting to study further.

\section{METHOD}

The present study is a descriptive qualitative research using ethnographic (Keating, 2001; Kuswarno, 2008) and Sociopragmatics (Pramujiono, 2012) designs. The research data were in the form of utterances in instructional interactions. The research data source was six Satya Wacana Christian University Salatiga (SWCU Salatiga) lecturers models. The data were collected using the participant observation records methods and fieldnotes (Sudaryanto, 2015), in addition, interviews were held with the lecturers being investigated. The data analysis was performed using descriptive techniques by following the interactive model of Milles and Huberman (1992) with the stages of data collection, data reduction, data presentation, and drawing conclusions.

\section{RESULT AND DISCUSSION RESULT}

Based on the results of data analysis, it indicated that the recount as a realization of a positive politeness strategy includes a recount about the lecturer, a recount about the student, a recount about the experience of the lecturer, and a recount about a public figure/public figure's attitude. Each recount is presented in the following explanation.

1) The recount of the lecturer himself

The recount of the lecturer as an effort to build close relationships with students can be seen in the following data.

(1) Ini pengalaman Pak Nardi. Bukan Pak Nardi mau memotretkan apa yang ada dalam Pak Nardi, tetapi Pak Nardi punya pengalaman yang diceritakan saja. Tahun 1990 Pak Naardi menjadi guru SD. Dan Pak Nardi kehilangan masa kerja karena Pak Nardi tidak dikontrak sehingga Pak Nardi kehilangan empat tahun. Masih golongan II. Bagaimana agar naik golongan III. Pak Nardi harus kuliah S1. Nah, dengan pendidikan saya mengejar golongan dari II A menjadi III A. Maka saya harus sekolah sarjana sehingga saya tidak mengalami golongan II B, II C, dan II D. Kalau itu ditempuh kan enam belas tahun. Kalau saya kuliah empat tahun saya lulus, maka ijazah saya langsung dihargai III-A. Nah, dengan pendidikan saya mengubah nasib saya. Saya kuliah lagi saya kuliah lagi dan terus dari guru SD saya menjadi dosen. Bukan keinginan saya untuk menjadi dosen, karena pada waktu itu saya ngomong kepada isteri saya. Saya ingin tampil percaya diri di kelas maka saya harus sarjana. Karena di sekolah sudah ada sarjana, saya ingin lebih tinggi lagi. Saya bukan apa-apa, saya ingin lebih tinggi lagi. Saya mengambil 
master, saya kuliah. Dan ternyata dari pendidikan itu mengubah nasib. Dan nasib saya berlabuh di UKSW ini menjadi lecture.

(This is Pak Nardi's experience. It's not that Pak Nardi wants to catch a glimpse of what is in Pak Nardi, but Pak Nardi has the experience to tell. In 1990 Pak Nardi became an elementary school teacher. And Pak Nardi lost his tenure because Pak Nardi was not contracted. Pak Nardi lost four years. Still in Group II of the Civil Servant Ranks. How to move up to Group III. Pak Nardi had to get a Bachelor's degree. Now, with education I pursued groups from II-A to III-A. So I had to go to graduate school so that I did not experience groups II-B, II-C, and II-D. If it had been that way, it would have taken sixteen years. If I had gone to college for four years, I would have graduated, so my diploma would immediately be appreciated as III-A. Now, with education I changed my destiny. I went to college again and I went back to school and from elementary school I became a lecturer. It was not my desire to become a lecturer, because at that time I spoke to my wife. I wanted to appear confident in class so I had to earn a bachelor degree. Because there were already graduates at school, I wanted to be even higher. I was a nobody, I wanted to be even higher. I took a master's degree, I went to college. And apparently from education it changed fate. And my fortune anchored at SWCU and became a lecturer).

The context of the previous utterance is the lecturer delivering material on the role of education on change. In giving a concrete example, the lecturer is telling of his career. In telling his experience, the lecturer used self-mentioning, Pak Nardi. Calling oneself this is one way to reduce $\mathrm{P}$ so that it feels more soothing, like a parent talking to his child. With concrete examples from one's own experience, the speaker wants to convince their students more about the role of education in changing one's destiny. The story also indirectly functions to instill character values to students. As cited by Lickona (2009) in (Pramujiono \& Nurjati, 2017), character inculcation can be done through modeling or modeling. In this context, the lecturer has given a real example of the character of hard work and responsibility.

2) Recounts of students

Recounts of students themselves as the efforts of speakers to build closeness with students can be seen in the following data.

(2) Nah, Aulia ini...mau jadi seperti ini mau jadi pinter mau jadi baik itu karena gesekan dari seseorang. Trus dia sesadar sadarnya tobat. Karena apa? Karena pernah bergesekan dengan keras sampai ke titik yang... sampai gak punya apa apa dia itu. Ei... kebetulan ketemu dengan teman yang cocok. Jadilah dia pandai berias. Jadi cantik. Dulu gak begini nih.... Tahu wajahnya tahun 2013 eh 2014 tidak seperti itu. Sekarang dia bergaul dengan perias manten itu. Dia jadi pandai merias. Dan mau kuliah.

(Well, this Aulia ... wants to be like this, wants to be smart, wants to be good because of the friction from someone. Then he was really really aware of $\mathrm{f}$ his repentance. Because of what? Because he had rubbed hard to the point that ... he didn't have anything. Hey ... happened to meet a proper friend. She's good at doing makeup. Sobeautiful. It wasn't like this back then ... I knew that her face in 2013, uh 2014 wasn't like that. Now he hangs out with the beautiful makeup. He became good at makeup. And want to go to college.) 
The context of the utterance above, the lecturer is giving the materials about the potential and dynamics. As a concrete example, the lecturer is telling the recount of a student's life journey. The interesting thing from the lecturer's recount is the direct mentioning of the name of the student, Aulia and the use of the greeting form, she. This phenomenon shows that the lecturer has closeness to his students. In addition, the lecturer also knows the life journey of the student so that it is used as an example in instilling character values to the students. Aside from being an effort to implement a positive politeness strategy, recounts of the student's self can be used to motivate other students, and instill character values to students.

3) Recounts of lecturers' experience

Stories about the experience of lecturers as speakers trying to build closeness with students can be seen in the following data.

(3) Kemarin saya ke Boyolali. Itu mak mak lo ya. Lulusannya wo luar biasa. Hanya S2 lo ya. SD SMP tapi eh... otaknya itu cerdas banget. Jadi kita hanya menyiapkan bahan-bahan yang sederhana itu tahu tahu jadi sesuatu yang menarik. Bisa jadi robot bisa jadi mobil-mobilan. Dalam waktu yang sangat singkat gitu. Mak mak lo ya. Mak mak gaweyane tiap hari hanya nggendhong anak. Tapi pikirannya kok keren. Hanya S2 lo ya. SD SMP tpi keren lo ya. Kalian S berapa? SD SMP SMP bahkan sudah ambil SI.

(Yesterday I went to Boyolali. That's a middle-aged woman. She graduated, wow extraordinary. Only got a master's degree... Middle schools but uh ... that she is really smart. So we only prepared simple ingredients, out of the blue, to be something interesting. Could be a robot ...could be a toy car. In such a short amount of time. Mak (Ma'am) why are you? What she is always doing everyday is carrying her child. But her brain is really cool. Only a master holder. Middle school, but you're cool. How many guys do you have? Elementary school... Middle school has even taken a bachelor's degree)

The context of the utterance above is the lecturer teaching the students about the importance of creativity. He told them about the Community Service experience in Boyolali. There are found mothers who have high creativity despite their low education. In telling stories, the lecturers used a choice of informal variety of words, thereby reducing the degree of formality. Mak, said, really smart, why are you cool? The use of informal forms in recounting can reduce social distance (D) and decrease Power (P) (Brown et al., 1987; Scollon et al., 2011) so that there is a closeness between lecturers and students. The above story can also be used to motivate students not to look down mothers whose education is low. In addition, it can also be used to instill the value of creative characters.

4) Recounts of public figure or attitude of the public figure

The Recounts of public figure or attitude of the public figure as a speaker's attempts to build closeness with students can be seen in the following data.

(4) Sucipto ini pedagogi dari UKSW. Dia filosof UKSW. Filosof local, termasuk gurunya Pak Nardi waktu itu. Pak Cipto ini waktu mengajar di UKSW di FKIP sebagai seorang pedagog seorang pendidik berpakaiannya kalau mengajar selalu berjas. Datang selalu pagi tidak pernah terlambat untuk mengjar.Jam tujuh ya sebelum jam tujuh sudah datang. Ada di dalam kelas. Lha yang celaka adalah kalau sekarang itu macam Brus ini pasti tidak suka. Orang yang sering telat bangun. 
Karena kalau pintu sudah ditutup seperti itu mahasiswa yang telat tidak diizinkan masuk. Nah kalau dengan Pak Cipto ini harus datang lebih pagi. Kalau sampek dalam perjalanan dari depan kampus ya... Di pinggir lapangan kalau Pak Cipto sudah datang mahasiswa tidak boleh mendahului. Semua berjalan di belakangnya. Hehehe... Semua berjalan di belakangnya. Kalau mau mendahului harus lari ke pinggir lapangan dulu. Jauh begitu supaya masuk lebih dulu di kelas. Jadi repot kan? Tapi cara mengajarnya bagus. Setiap tes yang diberikan oleh Pak Cipto tidak ada yang salah. Semuanya benar. Tapi ada nilainya....

(This Sucipto is a pedagogue from SWCU. He is a SWCU philosopher. As a local philosopher, including his teacher Pak Nardi at that time. Pak Cipto taught while at SWCU at FKIP as a pedagogue, an educator dressed when he always taught in suits. Always come early in the morning, never too late to teach. Seven o'clock... before seven o'clock he has arrived. In the class. What a wretch is that if it's like this Brus certainly doesn't like it. People often wake up late. Because if the door is closed like that, late students are not allowed to enter. Now if you come with Pak Cipto, you have to come earlier. If you come to the campus from the front of the campus, yes ... On the sidelines, if Pak Cipto has arrived, students must not go ahead. All goes behind him. Hahaha Everything goes behind him. If you want to overtake you have to run to the edge of the field first. So far in order to enter first in class. So it's troublesome right? But the way to teach is good. There was nothing wrong in every test given by Mr. Cipto. All are correct. But there is value ...)

The context of the utterance above, the lecturer is teaching the material of human nature, consciousness and self-awareness. The lecturer is talking about an educational figure at SWCU, Mr. Sucipto Wirosarjono. He was told that he was a pedagogue who was very disciplined and had a unique learning model. Through the recount of the public figure, the lecturer wants to instill the value of the disciplined character by emulating the character.

A recount of public figure's attitude in education, the lecturer admired Iwan Fals and told how the attitude of Iwan Fals as a parent towards his children's education.

(5) Nah, saya tertarik dengan Iwan Fals. Iwan Fals itu penyanyi yang membebaskan anaknya mau jadi apa. Dia tidak memaksakan anaknya untuk jadi pemusik seperti Bapaknya. Ya.... Membebaskan. Mau sekolah karepmu ora karepmu. Кати punya masa depan sendiri. Iwan Fals sebagai orang tua menyiapkan biaya. Kamu mau sekolah ke mana tak biayai, mau gak sekolah terserah kamu. Itu namanya orang tua tidak begitu campur tangan pada anaknya bahkan tidak memotretkan kepribadian, memotretkan dirinya pada anaknya.

(Well, I'm interested in Iwan Fals. Iwan Fals is a singer who freed his child to be. He did not force his son to be a musician like his father. Yes.... Freeing up. Want to go to school because of you. You have your own future. Iwan Fals as a parent preparing costs. You don't want to go to school, you don't want to go to school. It's called parents not so interfering with their children, not even photographing personalities, portraying themselves to their children.)

The context of the utterance, the lecturer is presenting the principles of individuality in education. Through this recount the lecturer wants to convey to students as prospective educators to emulate Iwan Fals who does not impose his will on his children. As prospective teachers, they will not be able to impose their will on the students. With this recount, the 
lecturer does not only build closeness with the students, but also instills pedagogical values to the students.

\section{DISCUSSION}

The use of recount in instructional interactions in lectures is an interesting phenomenon in the perspective of politeness theory. Brown et al. (1987) suggested five strategies in reducing face threatening acts, (1) direct speech acts/saying things in a direct, clear, unambiguous and concise way (bald on record), (2) speech acts using positive politeness strategies, (3) speech acts using negative politeness strategies, (4) speech acts in a disguised/indirect manner (off record), and (5) speaking in the heart or not doing speech acts.

The present study focuses on a language politeness strategy, that is, positive politeness. A positive politeness strategy is an effort to reduce distance and reduce the power of a speaker. It aims to protect the face, both the face of the speaker or the face of the speech partner. Brown et al. (1987) suggest the fifteen positive politeness sub-strategies. They include (1) paying attention to the listener's wants, desires, and needs, (2) exaggerating the attention, approval, and sympathy of the listener, (3) intensifying the listener's attention by dramatization of events or facts, (4) using group identity (forms of greeting, dialect, jargon or slang), (5) seeking agreement on a general topic or repeating parts/ all of the utterances, (6) avoiding disagreement by pretending to agree, pseudo-agreement, deceptive for good (white lies), hedging opinion. (7) showing things that are considered to have similarities through small talk and presuppositions, (8) using jokes, (9) stating that the listener's desires are understood, (10) giving an offer or promise, (11) showing optimism, (12) involving speakers or listeners in activities, (13) giving questions or asking reasons, (14) expressing reciprocal relationships, and (15) giving special attention (goods, sympathies, attention, cooperation) to the listener.

The use of recount can be added as a positive politeness sub-strategy. Using a recount, a lecturer can protect the student's face because he does not state directly to do something, for example, he or she gears the students to be more disciplined or to study harder to become a successful person. In the context of learning, recount can be used as an effort to build closeness between lecturers and students in order that that a conducive learning atmosphere is developed in the classroom (Pramujiono \& Nurjati, 2017). The conducive classroom atmosphere is expected to support the achievement of learning objectives.

The use of recounts can be used to instill character education through exemplary characters, for example, in instilling the value of discipline and willing to work hard. In addition, recounts can also be used to motivate students to optimize their potential and become creative students.

The closeness of lecturers and students developed through the use of positive politeness strategies has contributed to efforts to create humanistic learning. With the humanistic learning, interaction in the classroom is expected to be more harmonious and avoid conflicts. This is as designated by Leech (2016) using the politeness language can forge harmony and avoid conflict in an interaction.

These results are in accordance with Senowarsito (2013) revealing that the politeness strategies were employed by the teachers in giving instructions, giving explanations, showing appreciations, encouraging and motivating students as well as answering student's questions. The students were found to apply the politeness strategies mainly in providing responses to the teacher's instructions, questions and encouragements. Furthermore, the cultural background, i.e. the Indonesian and Javanese culture, were involved in applying the strategies, in which the power relation between teacher and students is often unequal- teacher is deemed to be more respectable than students; students should therefore act in a way that they should never threaten the teacher's face. 
This kind of softening mechanism was also discovered in Mahmud (2018) findings indicating that the English students used different kinds of expressions as their politeness strategies in the classroom communication. Those expressions were in the forms of greetings, thanking, addressing terms, apologizing, and fillers. They also included several particular terms derived from the students' vernacular language and used to reduce the FTA for their presentations.

The findings also support Peng, Xie, and Cai (2014). It was discovered that the English language teachers adopted the politeness strategies and it proved that they could shorten the teacher-student social distance, make the class interesting, and in turn facilitate the English teaching and learning.

In another context, i.e. in the academic writing, the results are also relevant to the study results of Getkham (2013) revealing the pragmatics of politeness in the scientific articles, in particular, the politeness strategies in regularities of scientific style. It was discovered in the discussion section of the research articles when the authors had conflicting views against some particular theories to minimize the impolite behaviors and constitute what Brown et al. (1987) call face threatening acts (FTAs).

In addition, the findings are consistent with (Pramujiono, 2008). His findings showed that the doctors and their patients also employed the politeness strategies while giving attention and empathy, using a joke, using abbreviations or acronyms, showing optimism, asking for reasons or giving questions, and requesting agreement by means of repeated utterances.

All in all, this study has supported that the politeness strategies are assigned differently depending on what particular context the speaker and the recipient are. The politeness strategies have proved to be instrumental in making a successful communication. This is what Brown \& Levinson (1987) consider as the heart of respect behavior because it performs the function of minimizing the imposition over the hearer.

\section{CONCLUSION}

Recounting can be used as one of the politeness sub-strategies as modeled by (Brown et al., 1987). Through recounting, closeness can be built between lecturers and students, especially if the lecturer wants to understand the character and background of each student's life. Based on the results of the data analysis, it indicated that the recount as a realization of a positive politeness strategy includes telling about the lecturer, the student, the experience of the lecturer, and a public figure/public figure's attitude. In addition to functioning to build closeness with students, recounts told by lecturers can serve to instill character values and to provide motivation to students in order that they are disciplined, to develop their potential and become creative students. The use of recount as a positive politeness substrategy has contributed to efforts to develop humanistic learning and build harmony in classroom interactions.

\section{Acknowledgements}

The authors would like to extend their deepest gratitude to the Indonesian Ministry of Research Technology and Higher Education that supported their research under the Fundamental Research Grant scheme (Skema Penelitian Dasar Unggulan Perguruan TinggiPDUPT), and Rector of Universitas PGRI Adi Buana Surabaya, Vice Dean I of Faculty of Teacher Training and Education of the same university, and Vice Dean I of Faculty of Teacher Training and Education of UKSW who provided the approval of conducting the research. 


\section{REFERENCE}

Brown, P., Levinson, S. C., \& Levinson, S. C. (1987). Politeness: Some Universals in Language Ssage (Vol. 4): Cambridge University Press.

Getkham, K. (2013). Politeness Strategies in Research Articles: A Cross-Disciplinary Study. Paper presented at the AACL International Conference, San Diego State University, California, USA.

Keating, E. (2001). The Ethnography of Communication. In P. Atkinson (Ed.), Handbook of Ethnography. Los Angele: Sage Publications.

Kuswarno, E. (2008). Etnografi Komunikasi suatu Pengantar dan Contoh Penelitiannya. Bandung: Widya Padjadjaran.

Leech, G. N. (2016). Principles of Pragmatics. New York: Longman.

Lickona, T. (2009). Educating for Character: How Our Schools can Teach Respect and Responsibility. New York: A Bantam Book Publishing History.

Mahmud, M. (2018). The Use of Politeness Strategies in the Classroom Context by English University Students. Indonesian Journal of Applied Linguistics, 8(3), 597-606.

Milles, M. B., \& Huberman, A. M. (Eds.). (1992). Analisis Data Kualitatif: Buku Sumber Tentang Metode-Metode Baru.

Peng, L., Xie, F., \& Cai, L. (2014). A Case Study of College Teacher's Politeness Strategy in EFL Classroom. Theory and practice in language studies, 4(1), 110-122.

Pramujiono, A. (2008). Kesantunan Positif Komunikasi Dokter-Pasien dalam Program Konsultasi Seks. Linguistik Indonesia: Jurnal Ilmiah Masyrakat Linguistik Indonesia, 26(2), 151-167.

Pramujiono, A. (2012). Kesantunan Berbahasa dalam Wacana Dialog di Televisi. Disertasi Doktor Tidak Diterbitkan. Surabaya: PPs UNESA [Program Pascasarjana Universitas Negeri Surabaya].

Pramujiono, A., \& Nurjati, N. (2017). Guru sebagai Model Kesantunan Berbahasa dalam Interaksi Instruksional di Sekolah Dasar. MIMBAR PENDIDIKAN Jurnal Indonesia untuk Kajian Pedidikan, 2(2), 143-154.

Scollon, R., Scollon, S. W., \& Jones, R. H. (2011). Intercultural Communication: A Discourse Approach. Malden: Blackwell Publishing.

Senowarsito, S. (2013). Politeness Strategies in Teacher-Student Interaction in an EFL Classroom Context. TEFLIN Journal, 24(1), 82-96. doi: https://doi.org/10.15639/teflinjournal.v24i1/82-96

Sudaryanto. (2015). Metode dan Aneka Teknik Analisis Bahasa: Pengantar Penelitian Wahana Kebudayaan secara Linguistis. Yogyakarta: Sanata Dharma University Press. 